\title{
DELAPAN GERAKAN PIJAT SEHAT
}

\author{
Ni Made Sinarsari \\ Program Studi Kesehatan Ayurweda,Fakultas Kesehatan \\ Universitas Hindu Indonesia Denpasar \\ Email : sinarsari73@gmail.com
}

\begin{abstract}
Abstrak
Sehat merupakan keadaan sejahtera dari badan, jiwa, sosial yang memungkinkan hidup produktif secara sosial dan ekonomi. Sehat dilihat sebagai satu kesatuan yang utuh terdiri dari unsur unsur fisik, mental, sosial dan didalamnya kesehatan jiwa merupakan bagian integral kesehatan. Faktor - faktor yang mempengaruhi kesehatan meliputi nutrisi yang lengkap dan seimbang, istirahat yang cukup, olahraga yang teratur, kondisi mental, sosial dan rohani yang seimbang, lingkungan yang bersih. Olahraga yang teratur merupakah salah satu upaya hidup sehat. Gerakan tubuh secara teratur membuat persediaan jumlah oksigen, nutrisi dalam jaringan tubuh menjadi maksimal. Variasi dalam Gerakan fisik dapat dilakukan melalui memadukan Gerakan fisik dengan pijat. Pijat dilakukan pada beberpaa titik di dalam tubuh, yang fungsinya melancarkan peredaran darah, merilekskan serta menjadikan tubuh sehat dan bugar. Gerakan pijat mengambil titik - titik point dalam tubuh. Dengan pijatan memberikan manfaat kepada tubuh. Pijatan yang diberikan dengan melakukan ketukan, tekanan yang teratur berirama dengan memadukan unsur-unsur alamiah serta bersinergi dengan semesta
\end{abstract}

Keywords : Gerakan, Pijat, Sehat

\begin{abstract}
Health is a state of well-being of the body, soul, and social that makes it possible to live productively socially and economically. Health is seen as an integrated whole consisting of physical, mental, social elements and mental health is an integral part of health. Factors affecting health include complete and balanced nutrition, adequate rest, regular exercise, balanced mental, social and spiritual conditions, a clean environment. Regular exercise is an effort to live a healthy life. Regular body movements make the supply of the maximum amount of oxygen, nutrients in body tissue. Variations in Physical Movement can be done through combining Physical Movement with massage. Massage is carried out on several points in the body, which functions to improve blood circulation, relax and make the body healthy and fit. Massage movements take points in the body. With massage provides benefits to the body. A massage that is given by doing regular, rhythmic pressures by combining natural elements and synergizing with the universe
\end{abstract}

Keywords: Movement, Massage, Healthy 


\section{PENDAHULUAN}

Ayurweda memandang kesehatan secara keseluruhan. Ayurweda memelihara manusia sebagai bagian dari alam semesta yang terdiri dari materi yang sama yakni api, tanah, udara, air dan akasa/ ruang. Tri dasha (Teori Tiga Elemen) materi merupakan dasar dari ayurweda yang terdiri dari vatta (udara), pitta (api) dan kapha (air). Dikatakan sehat bila ketiga unsur ini seimbang.

Bila keseimbangannya terganggu (meningkat atau menurun) akan menimbulkan berbagai penyakit. Bila terjadi keseimbangan didalam tubuh akan mengakibatkan Gerakan nafas dan Gerakan tubuh lancar, cepat mengerti, pembuangan limbah tubuh lancar, penglihatan lancar, pendengeran kuat.

Delapan Gerakan pijat sehat merupakan salah satu upaya yang bisa

\section{PEMBAHASAN}

\subsection{Delapan Gerakan Pijat Sehat}

\subsubsection{Pengertian}

Delapan gerakan yang dilakukan dengan memberikan sentuhan berupa ketukan, tekanan, yang teratur, berirama pada titik titik poin dalam tubuh memberikan manfaat kepada tubuh jasmani, rohani dengan memadukan unsur - unsur alamiah serta bersinergi dengan semesta

\subsubsection{Tujuan}

a. Meningkatkan fleksibilitas tubuh

b. Melancarkan sirkulasi darah

c. Meningkatkan keseimbangan dan koordinasi

d. Meningkatkan kemampuan fisik

e. Meningkatkan kebugaran tubuh

f. Mengurangi risiko nyeri punggu dan bagian bawah

g. Mengurangi stress

\subsubsection{Durasi}

Durasi pelaksanaan 8 gerakan pijat sehat adalah 1 menit

\subsubsection{Prosedur 8 Gerakan Pijat Sehat}

Hal pertama yang harus dilakukan adalah ambil posisi senyaman mungkin dengan cara duduk atau berdiri, selanjutnya posisi tulang belakang tegak namun tetap rileks. dilakukan agar terjadi keseimbangan didalam tubuh. Delapan Gerakan pijat sehat sebagai bagian dari aktivitas fisik. Aktivitas fisik adalah gerakan tubuh yang dihasilkan oleh otot - otot rangka yang dihasilkan sebagai suatu pengeluaran tenaga yang meliputi pekerjaan, waktu senggang serta aktivitas sehari - hari. Aktivitas fisik memerlukan usaha ringan, sedang, berat yang dapat menyebabkan perbaikan kesehatan bila dilakukan secara teratur

Delapan gerakan pijat sehat memadukan antara aktivitas fisik dengan sentuhan (pijatan). Gerakan tubuh dibarangi dengan melakukan penekanan pada titik - titik tertentu di dalam tubuh, yang memberikan manfaat bagi kesehatan.

\section{Gerakan Satu}

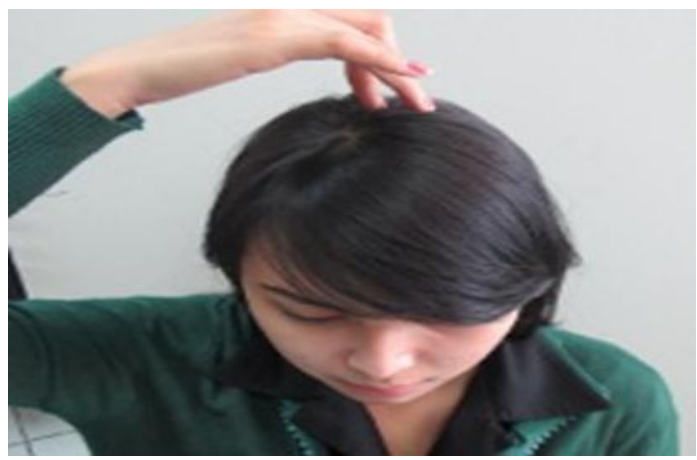

Nama : Titik Baihui ( titik ratusan pertemuan )

Fungsi : mengatasi masalah kepala dan indra perasa,

memelihara sumsum,

otak, menstimulasi perkembangan menenangkan otak cara :

a. Letakan kedua ibu jari di ujung telinga

b. Tangan telunjuk disatukan pada puncak kepala

c. Ketuk atau tekan secara teratur, berirama

d. Dalam hitungan 3 ketukan atau 3 irama

\section{Gerakan Dua}




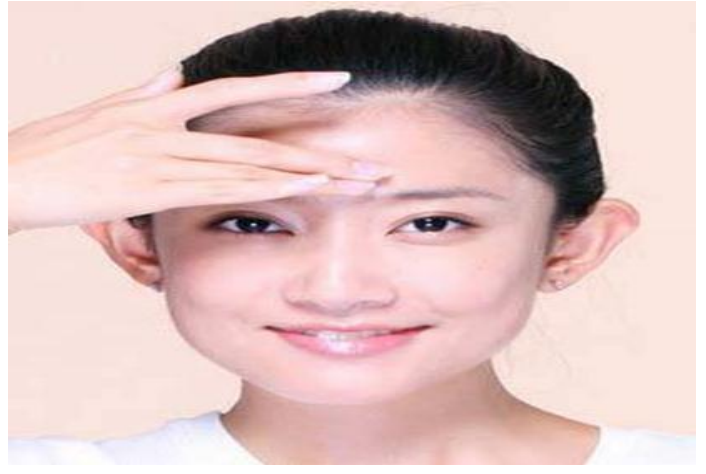

Nama : Titik Yintang ( mata ketiga )

Fungsi : menstabilkan endokrin, menjernihkan kekacauan

pikiran, megatasi ketidak seimbangan

mata, mengatasi masalah kepala, menstabilkan kekacauan

perasaan,

stimulasi perkembangan otak cara:

a. Letakan jari telunjuk atau jari tengah di antara kedua alis

b. Lakukan ketuk atau tekan secara teratur, berirama

c. dalam hitungan 3 ketukan atau 3 irama

\section{Gerakan Tiga}

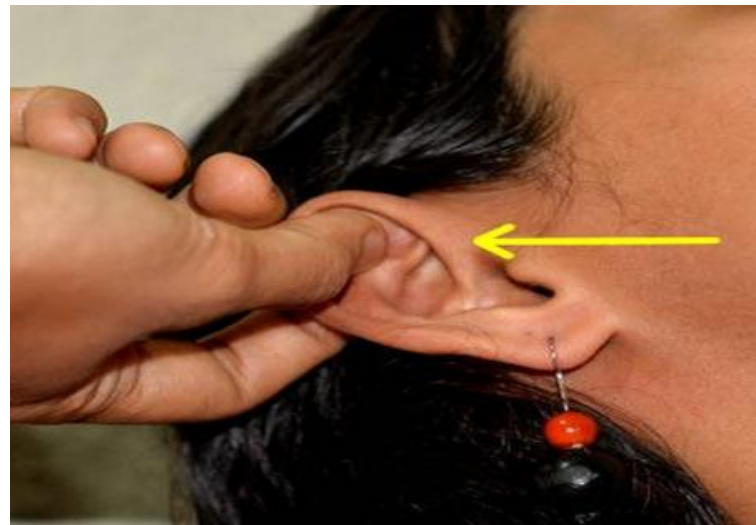

Nama : Titik Puncak Telinga

Fungsi : mengembalikan kondisi tubuh agar tetap sehat,

mengatasi rasa nyeri,

meredakan nyeri punggung dan

bahu

telinga,

$$
\text { mengatasi gangguan pada }
$$

stimulasi perkembangan otak

Cara:

a. Letakan kedua ibu jari, telunjuk tangna pada ujung telinga bagian atas b. Jepit ujung telingan dengan ibu jari dan telunjuk secara teratur dan berirama

c. Dalam hitungan tiga

\section{Gerakan Empat}

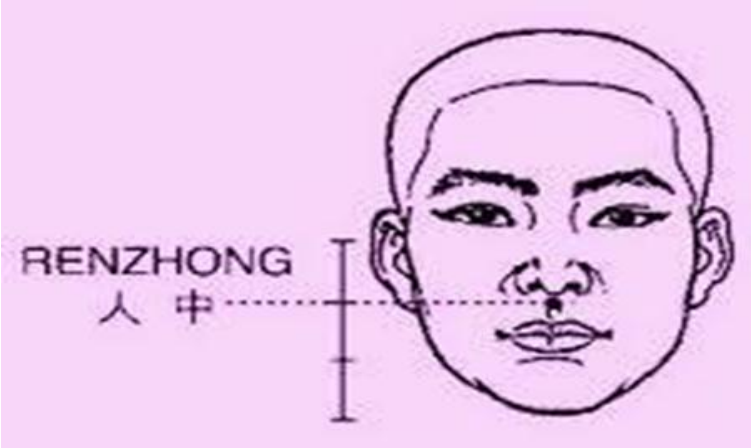

\section{Nama : Renzhong \\ Fungsi : mengembalikan kesadaran, menenangkan pikiran, ketidakseimbangan mental,}

Cara:
a. Letakkan telunjuk atau jari tengah dibawah hidung, jalur lekuk diatas tengah - tengah bibir atas
b. Ketuk atau tekan secara teratur, berirama
c. 3 ketukan \& irama

\section{Gerakan Lima}

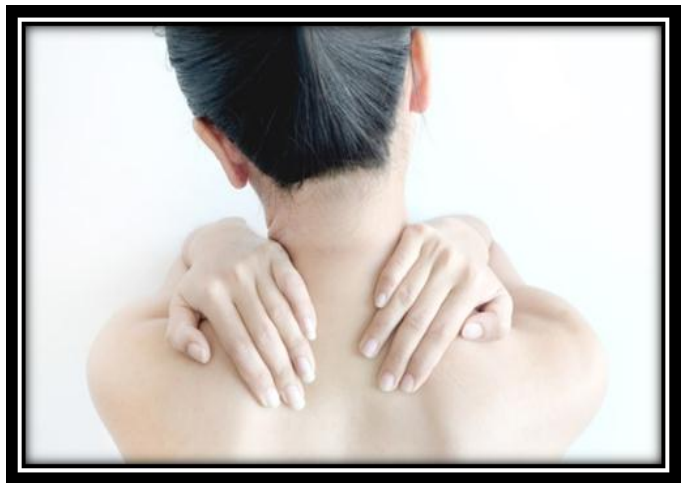

Nama : Titik Jian Jing

Fungsi : mengatasi kaku leher, punggung, kekakuan lengan,

memberikan ketenangan

Cara:

a. Letakan kedua tangan pada pertengah Pundak

b. Gerakan tangan memutar secara teratur dan berirama 
c. Tiga hitungan ketukan

\section{Gerakan Enam}

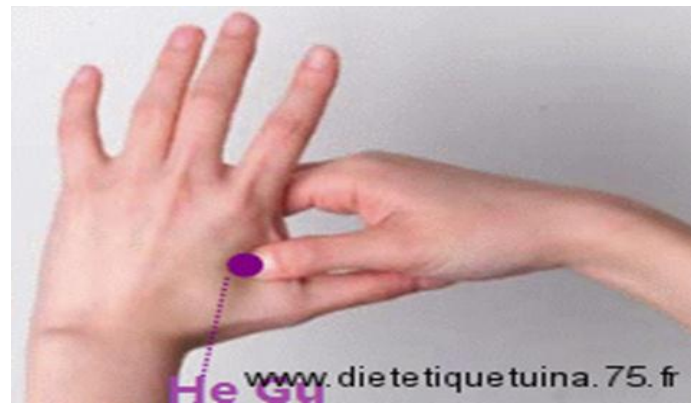

Nama : Hegu ( Persimpangan jalan lembah)

Fungsi : setiap kondisi yang berhubungan dengan wajah dan kepala, mengatasi rasa sakit

Cara:

a. Buka lalu regangkan ibu jari dan jari telunjuk, lalu pada lipatan ibu jari dan jari telunjuk tempat yang ujung jempol meluas.

b. Tekan atau ketuk secara teratur, berirama

c. 3 ketukan atau irama

\section{Gerakan Tujuh}

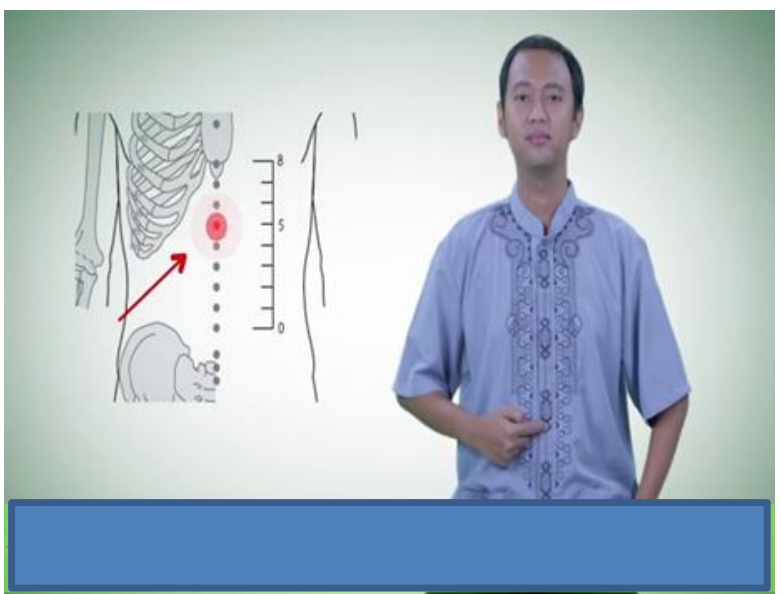

Nama : Zhong Wan

Fungsi : meningkatkan fungsi limpa, lambung

stamina

mengatasi nyeri lambung, untuk

Cara:

a. Letakkan kedua telunjuk pada pertengahan ulu hati dan pusar

b. Tekan atau ketuk 3 ketukan, irama secara teratur, berirama

\section{Gerakan Delapan}

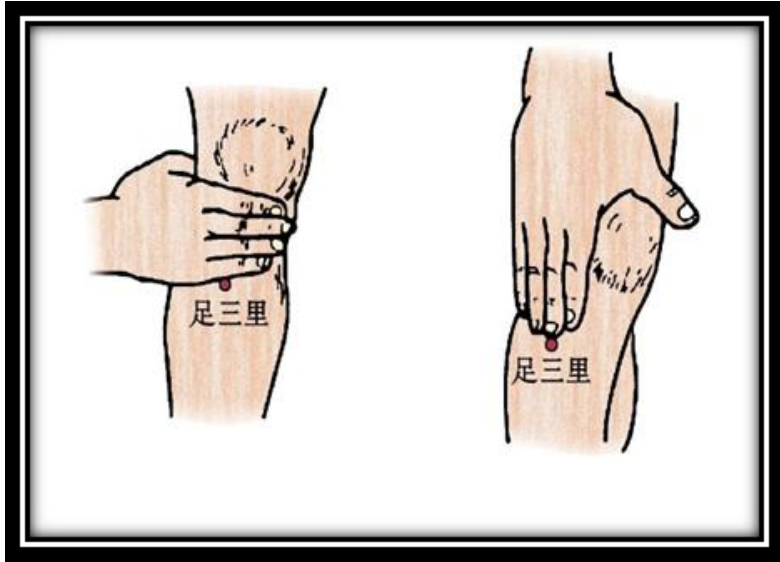

Nama : Zu San Li

Fungsi : daya tahan tubuh, meningkatkan fungsi limfa,

lambung

Cara:

a. Letakkan 4 jari di bawah tempurung lutut, 1 jari di susu luar tulang kering

b. Tekan atau ketuk teratur, berirama 3 ketukan

\section{Gerakan Penutup}

a. Badan posisi bungkuk membentuk sudut $90^{\circ}$

b. Tangan lurus kearah bumi

c. Tarik nafas dari hidung, kembungkan perut

d. Angkat kedua tangan keatas sambal ucapkan SE

e. Hembuskan nafas

f. Tangan membentuk huruf U

g. Sejajar kedua Pundak

h. Jari di kepalkan

i. Ucapkan SEHAT

\section{SIMPULAN}

Kesehatan merupakan suatu hal yang sangat penting dalam kehidupan manusia, kesehatan merupakan keadaan sejahtera dari badan, jiwa, sosial yang memungkinkan untuk hidup produktif secara sosial dan ekonomi. Kesehatan dilihat sebagai satu kesatuan yang utuh terdiri dari unsur - unsur fisik, mental, sosial didalamnya terdapat unsur jiwa. Bila terjadi keseimbangan didalam tubuh akan mengakibatkan gerakan nafas, gerakan tubuh lancar, cepat mengerti, pembuangan limbah tubuh lancar, penglihatan tajam, pendengaran kuat. Salah satu upaya untuk hidup sehat 
adalah melakukan aktivitas fisik, seperti olah gerak. Delapan gerakan pijat sehat sebagai salah satu upaya hidup sehat dengan memadukan aktivitas fisik dengan sentuhan (pijatan) pada titik - titik tertentu di dalam tubuh yang bermanfaat untuk kesehatan tubuh secara optimal

\section{DAFTAR PUSTAKA}

Aslani, Marilyn, 2003. Teknik Pijat untuk Pemula. Erlangga: Jakarta

Dash, Vaidya Bhagawan, 2006. Ayurweda Ilmu Pengobatan Tradisional India. Paramita: Surabaya Marcus Munafto,P.2011. Psikologi Kesehatan.
Palmall

Mahmud,D. 2011. Buku Pintar Sehat Seumur Hidup. Saran Kesehatan Jakarta.

Nala,Ngurah. 1992. Usada Bali. PT Upada Sastra: Denpasar

Nala, Ngurah. 2001. Ayurweda Ilmu Kedokteran Hindu. Upada Sastra Denpasar

Nala, Ngurah, 2006. Aksara Bali dalam Usada. Paramita: Surabaya

Rajin M, 2015. Panduan Babon Akupuntur. Indoliterasi: Yogyakarta

Sukanta, 2008. Pijat Akupressure untuk Kesehatan. Penebar Plus: Jakarta

Wibawa, Aripta, Made, 2009. Ayurweda Pengetahuan Holistik. Bali Aga: Denpasar 